\title{
Histopathological alterations in gills of freshwater prawn, Macrobrachium dayanum (Crustacea - Decapoda) after acute and sub-acute exposure of lead nitrate
}

\author{
Sanjive Shukla* \\ Department of Zoology, B.S.N.V. P.G. College, Lucknow-226001 (U.P.), India \\ Kunwer Ji Tiwari \\ Department of Zoology, University of Lucknow, Lucknow-226007 (U.P.), India \\ Harnam Singh Lodhi \\ Department of Zoology, Saket P.G. College, Ayodhya, Faizabad-224123 (U.P.), India \\ Sandeep Shukla \\ Department of Zoology, University of Lucknow, Lucknow-226 007 (U.P.), India \\ Anand Mishra \\ Department of Zoology, B.S.N.V. P.G. College, Lucknow - 226001 (U.P.), India \\ U. D. Sharma \\ Retd. Professor, Department of Zoology, University of Lucknow, Lucknow-226 007 (U.P.), \\ India \\ ${ }^{*}$ Corresponding author. E-mail: sanjiveshukla@gmail.com

\begin{abstract}
Lead is a nonessential "grey listed" heavy metal, used in fuels, ceramics, paints and glass wares in industries and vehicles. After taking entry in aquatic ecosystem it becomes toxic and cause serious problem to plants and animals. Haematological, neurological, nephrological and histopathological effects of lead are well known. Fresh water prawn, Macrobrachium dayanum, a potential animal for freshwater aquaculture, subjected to acute and sub-acute concentration of lead nitrate $\left(116.46 \mathrm{mg} / \mathrm{l} ; 96 \mathrm{~h} \mathrm{LC} \mathrm{LC}_{50}\right.$ and $29.12 \mathrm{mg} / \mathrm{l} ; 25 \%$ of 96h $\mathrm{LC}_{50}$ ) showed severe histopathological alterations in gills after 24, 48, 72 and $96 \mathrm{~h}$ and 10, 20 and 30 day exposure. Chief alterations during acute exposure were thickening of gill plates, reduction in inter lameller spaces, cuticular irruption, inflammation and necrosis where as clumping of gill plates, hyperplasia, hypertrophied haemocytes with nuclear pycnosis and leakage of haemocytes in inter-lameller spaces as well as deposition of broken tissue debris near gill base were observed during sub-acute exposure. The severity of histopathological alterations was found duration dependant. Present study reveals that histological bio- markers provides complete information regarding heavy metal toxicity particularly lead to these economically important fresh water prawns, which can themselves serve as bio-indicator of worsening status of surface aquatic bodies.
\end{abstract}

Keywords: Fresh water Prawn, Gills, Histopathology, Lead toxicity, Macrobrachium dayanum

\section{INTRODUCTION}

Population explosion, rapid industrialization, intensive chemical use in agriculture and anthropogenic activities led to intensive deterioration of aquatic ecosystem there by adversely affecting the aquatic flora and fauna (Jarup, 2003; Sharma and Agrawal, 2005). Among toxicants, heavy metals are lethal because of their long half life, persistence, bioaccumulation and biomagnification tendency in the food chain there by increasing the problem many folds (Burman and Lal, 1994; Rouzbahani, 2017). Now a day's heavy metal contamination has become a major environmental issue (Mason, 1996; Chopra et al., 2009; Kumar and Chopra; 2015).

Among heavy metals, lead is a ubiquitous environmental contaminant and belongs to the group of

\section{Article Info}

DOI:10.31018/jans.v11i2.2118

Received: May 7, 2019

Revised: June 4, 2019

Accepted: June 10, 2019

\section{How to Cite}

Shukla, S. et al. (2019). Histopathological alterations in gills of freshwater prawn, Macrobrachium dayanum (Crustacea Decapoda) after acute and sub-acute exposure of lead nitrate. Journal of Applied and Natural Science, 11 (2): 568 - 574 https:// doi.org/10.31018/ jans.v11i2.2118 
al., 2016). Smaller fresh water prawns like M. lamarrei and $M$. dayanum despite having economic value, potential for good lab model and bioidicator as well as having potential for their aquaculture have not been taken into consideration except few studies (Shukla And Sharma, 2010; Verma et al., 2010; Tripathi et al., 2019). Crustacean gills are important for respiration, excretion, acid-base balance and osmotic and ionic regulation (Pequex, 1995; Soegianto et al., 1999; Lucu and Towle, 2003; Sabu et al., 2017). Gills are the first organs which comes in direct contact with the pollutants present in surrounding medium and are the major sites through which waterborne pollutants take entry in the body as well as affecting gills itself (Soegianto et al., 1999a)

Considering histology as a promising tool which provides complete picture of cell and tissue damage, the present work was undertaken to evaluate the histopathological effects of lead nitrate on gills of fresh water prawn, Macrobrachium dayanum (Crustacea-Decapoda), an untapped animal resource for freshwater crustacean aquaculture.

\section{MATERIALS AND METHODS}

Fresh water prawns, M. dayanum (Henderson) were collected from river Gomti, Lucknow (U. P.) - INDIA, with the help of local fisherman and brought to the laboratory ( $\mathrm{N}-26^{\circ} 49^{\prime} 55^{\prime \prime} \mathrm{E}-80^{\circ} 55^{\prime}$ $\left.58^{\prime \prime}\right)$ in large plastic containers. The animals were maintained in glass aquaria of 20 liter capacity containing 10 liter dechlorinated water having physico-chemical characteristics as follows: - $\mathrm{pH}-$ $7.66 \pm 0.27$, Temperature $-27.66 \pm 0.66^{\circ} \mathrm{C}$, D.O. - $6.6 \pm 0.74 \mathrm{mg} / \mathrm{l}$, Total Hardness - 268 $\pm 2.67 \mathrm{mg} /$ I, Alkalinity - 425 $\pm 11.36 \mathrm{mg} / \mathrm{l}$ (Sharma and Shukla, 1990; APHA et al., 1998).

Stock solution of lead nitrate $\left(\mathrm{Pb}\left(\mathrm{NO}_{3}\right)_{2}\right), \mathrm{AR}$ Grade molecular weight $331.21 \mathrm{gm} / \mathrm{mole}$, (EMerck (INDIA) Ltd. Worli Mumbai-400018) was prepared by dissolving weighed amount of salt in double distilled water. Lead nitrate was dissolved in water by adding, $0.3 \mathrm{mg} /$ liter of concentrated Nitric acid (Devi and Fingerman, 1995).

Adult inter-moult staged $M$. dayanum (Average length $-5.64 \pm 0.42 \mathrm{~cm}$; weight $-3.262 \pm 0.68$ gm.) were being utilized in experiments after 5-7 days acclimation to laboratory conditions. Acute exposure was carried out on $96 \mathrm{~h}$ LC $_{50}$ (116.46 $\mathrm{mg} /$ liter) for 24, 48, 72 and $96 \mathrm{~h}$ while sub-acute exposure was carried out on $25 \%$ of $96 \mathrm{~h} \mathrm{LC}_{50}$ (29.12 mg/liter) for 10,20 and 30 day respectively. One aquarium containing diluents water and 0.3 $\mathrm{ml} /$ liter conc. Nitric acid only served as control for each set. Feeding was suspended $24 \mathrm{~h}$ prior to acute exposure and through out experiment while change of exposure medium and food supply were maintained on alternate day during subacute exposure. Continuous air supply was provided by air diffusers and aerators in both control as well as experimental aquaria in both the experiments. Both acute and sub-acute experiments were carried out according to guideline of APHA et al., (1998). Experiments were replicated thrice. Histopathological observations were taken into account after24, 48, 72 and 96h in acute, while after 10, 20 and 30 day in sub-acute exposure on live animals only. Gills of control as well as experimental animals were carefully dissected out under stereoscopic dissecting binocular, washed in Crustacean Ringer's solution (Brown and Creedy, 1970) and fixed in alcoholic Bouin's fluid for $24 \mathrm{~h}$. Tissue were dehydrated and imbedded in paraffin wax $\left(60-62^{\circ} \mathrm{C}\right)$. Serial sections of $6-8 \mu$ thickness were cut on rotary microtome, flattened on albuminized slides and stained with Harri's Haemotoxylin and Eosin by routine histological procedure (Drury and Wallington, 1980). Stained sections were observed and photographed under Olympus trinocular microscope comparing with controls.

\section{RESULTS AND DISCUSSION}

Freshwater prawn, $M$. dayanum consists of eight pairs of gills on lateral sides which are typically phyllobranch type and almost similar to Palaemon (Patwardhan, 1937). Gill consists of gill base on which two rows of gill plates are found. Rhomboidal gill plates are arranged on the gill base like the leaves of a book. Gills are attached to the body through gill roots. The gills of control prawns (Plate-1, Figs. 1-2) appeared normal with spaced gill plates; cuticle appeared smooth and regular along with normal number of circulating haemocytes. Gills are the primary site which directly comes in contact of the surrounding medium and are affected by the toxicants. Gills, the chief respiratory organs of fresh water prawn, $M$. dayanum showed pronounced histopathological changes after acute and sub-acute exposure of Lead nitrate are as follows:

After 24 hr exposure (Plate 2, Figs. 1, 2), inflammation, vacuolization and distention of gill plates were observed. After $48 \mathrm{hr}$ exposure (Plate 2, Figs $-3,4)$, cuticular eruption and bulging of gills plate tip were common. Hyperplasia was seen at most of the places. Mucous coating was observed on gill plates. After $72 \mathrm{hr}$ exposure (Plate 2, Figs. 5, $6)$, most of the gill plates were found clumped due to hyperplasia reducing interlamellar space further. Leakage of haemocytes and tissue debris in the interlamellar spaces were prominent. Circulating haemocytes showed pyknosis and karyorrhexis. After $96 \mathrm{hr}$ exposure (Plate 2, Figs. 7, 8), due to severe necrotic and degenerative changes general architecture of gills was found almost lost. Tips of gill plates were bulge and almost found stucked together along with granular deposition in it. Haemocytes and tissue debris were found filled in interlamellar spaces. 
Shukla, S. et al. / J. Appl. \& Nat. Sci. 11(2): 568 - 574 (2019)
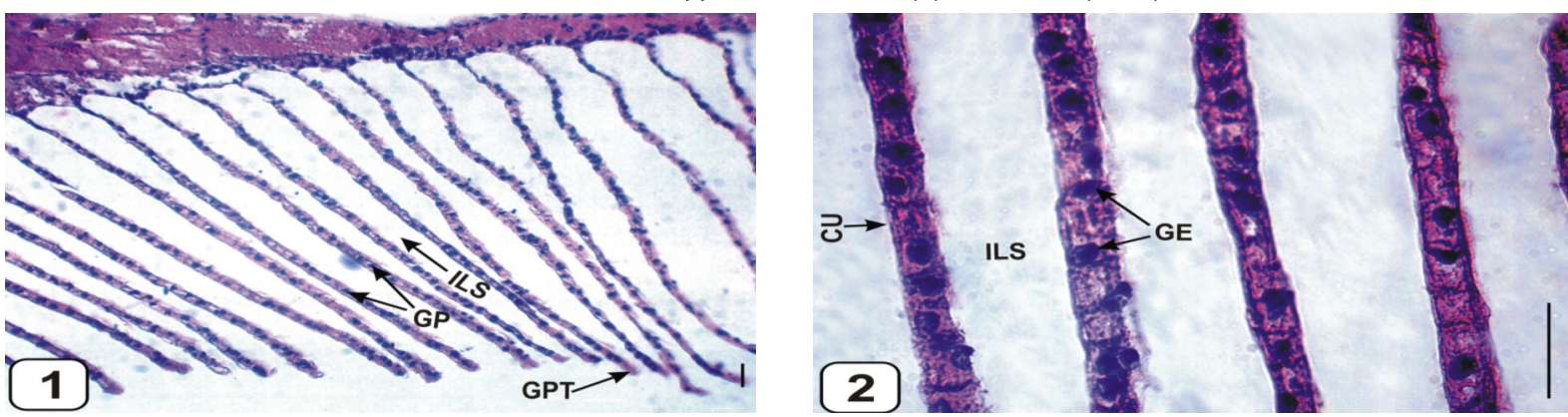

Plate 1-Figs.1-2. Photomicrographs of T.S. of Gill (Control), Scale bar= $50 \mu$ [CU=Cuticle, GE=Gill Epithellium, GP=Gill Plate, GPT=Gill Plate Tip, ILS=Inter lamellar space]
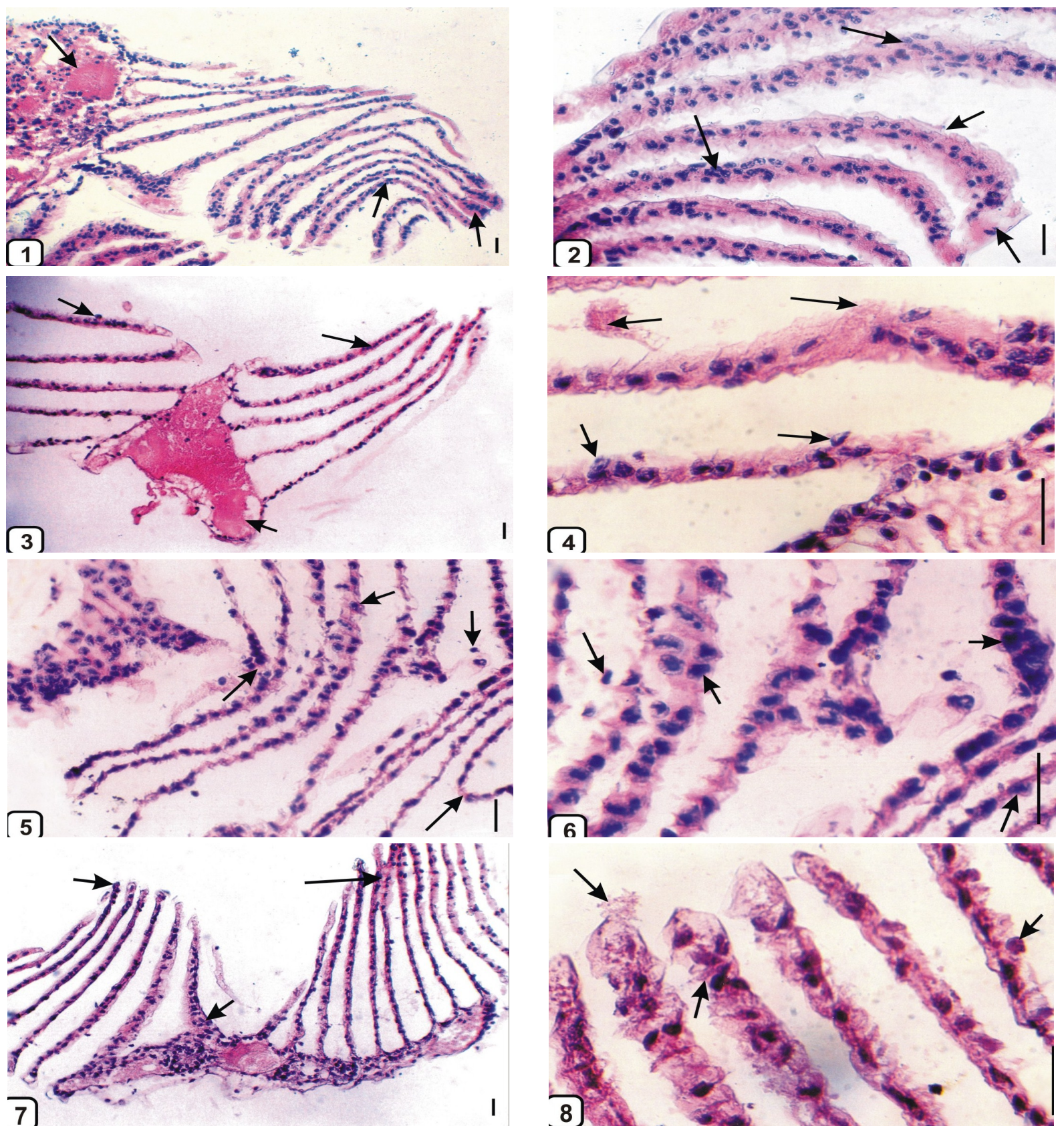

Plate 2-Figs. 1-8. Photomicrographs of T.S. of Gills showing the effects of acute exposure of Lead nitrate, Figs. -1 and 2 after 24 hr; Figs. -3 and 4 after 48 hr, Figs. -5 and 6 after 72 hr; Figs. -7 and 8 after 96hr, Scale bar= $50 \mu$. 
Shukla, S. et al. / J. Appl. \& Nat. Sci. 11(2): 568 - 574 (2019)
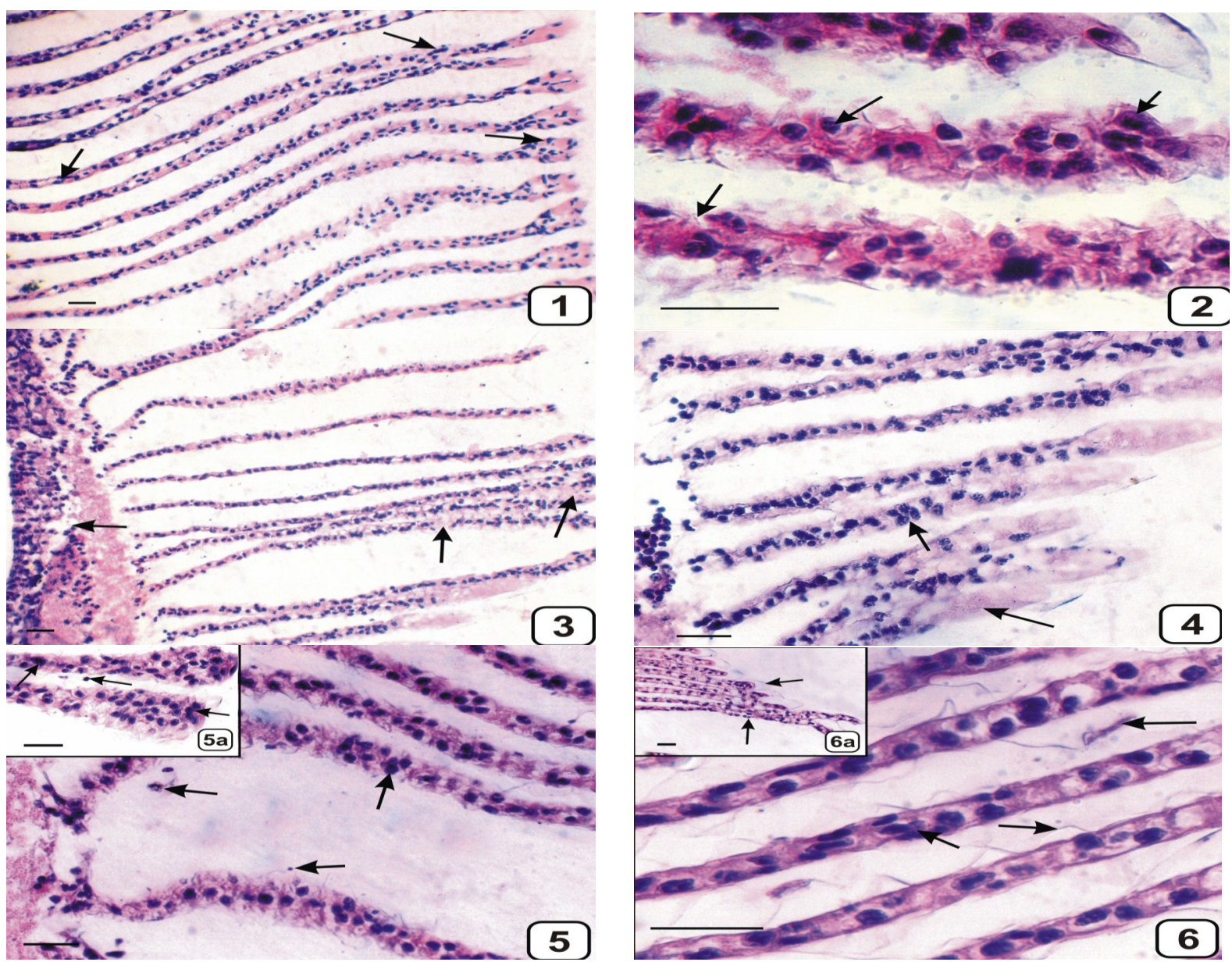

Plate 3-Figs.1-6. Photomicrographs of T.S. of Gills showing the effects of sub-acute exposure of Lead nitrate, Figs. -1 and 2 after 10 day; Figs.-3 and 4 after 20 day; Figs.- 5,5a, 6 and 6a after 30 day, Scale bar= $50 \mu$

After 10 day exposure (Plate 1, Figs., 4), inflammation and distention in the gill plates was observed. Cuticular eruption and necrosis was common in most of the gill plates while hyperplasia was seen at some places. Very mild leakage of haemocytes in inter tubular spaces was found. After 20 day exposure (Plate 1, Figs. 5, 6), inflammation and hyperplasia was found increasing in gill plates which resulted in highly reduced inter lamellar spaces. Increased influx of haemocyte was noticed at this stage. Most of the gill tips were found filled with Granular haemocytes and Cystocytes. After 30 day exposure (Plate 1, Figs. 7 and $7 a, 8$ and $8 a$ ), hyperplasia was pronounced in most of gill plates. Necrotic and degenerative changes were common showing pycnosis and karyolysis. Cuticular eruption was highly common. Gill tips were highly bulged and found filled with granular depositions and haemocytes. Most of the gill tips were found stucked together leaving almost no inter lameller spaces.

Freshwater prawn, M. dayanum consists of eight pairs of gills or branchiae which are typically phyllobranch type having rhomboidal gill plates arranged on triangular gill base (Patwardhan, 1937).
Gill are not only the organ of respiration but are also potent osmoregulatory structure and comes in direct contact of surrounding medium and toxicant present in medium hence are more affected than any other part of the body. Heavy metals are well known to reduce oxygen consumption as well as disruption of osmoregulation in crustaceans (Jadhav, 1993; Sen et al., 2008; Asih et al., 2013; Putranto et al., 2014; Soegianto et al., 2016 ).

In the present study, histopathological alterations like inflammation, vacuolization, distention of gill plates, hypertrophy and cuticular irruption, cell necrosis, bulging in gill plate tip, hyperplasia, heavy influx of haemocytes, thickening of gill plates and reduction in interlamellar space, collection of granular material below cuticle and leakage of haemocytes in interlamellar spaces, mucous coating after $96 \mathrm{hr}$ acute exposure and clumping of gill plates, necrotic and degenerative changes showing pycnosis and karyolysis, increased influx of haemocytes, fragmentation of nuclear material in haemocyte and aggregate of haemocyte noticed in haemolymph channel in gill base after 30 day sub-acute exposure, were the major alterations after lead nitrate exposure of $M$. dayanum. 
Gills showed almost complete disorganization after acute and sub-acute exposure of Lead in $M$. dayanum. Various workers reported almost similar histopathological alterations in gills of fishes and crustaceans after exposure of Lead and other heavy metals (Costa, 1965; Anderson and Baatrup; 1988; Gill et al., 1988; Khangarot and Tripathi, 1990; Kumari and Kumar, 1995; Jadhav, 1993; Dutta et al., 1996; Parashar and Banerjee, 2002; Olojo et al., 2005; Asih et al., 2013; Putranto et al., 2014; Soegianto et al., 2016; Frías -Espericueta et al., 2016).

Metal and toxic chemical caused haemocyte infiltration in gills and distension of gill plates as observed in present study. Similar type of haemocyte infiltration has been reported by various workers in crustaceans (Nimmo et al., 1977; Ghate and Mulherkar, 1979; Ghate, 1984; Anderson and Baatrup, 1988; Victor et al., 1990; Abraham and Radhakrishna, 2002). Gills play major in role in metal elimination in crustaceans. Haemocyte collect metal from circulation, transport to gills, accumulate within gill tissues and eliminated by sloughing of affected portion of gills. Similar type of accumulation and elimination by gills, hepatopancreas and haemocytes have been studied of clearance of carmine particles in shrimps (Fontine and Lightener, 1974).

Crustacean gills provide most permeable part of integument that's why they are not only site of respiration but also of osmoregulation. Gill are the primary site which come in direct contact of external environment ( Love Grove and Eddy, 1982) and pollutants which are present in it hence it is primary site for bioaccumulation and excretion of heavy metals in aquatic animals and similarly in decapod crustaceans (Hutcheson, 1974)

Heavy metals such as Mercury, Cadmium, Copper, Lead and Nickel precipitates gill secretion and restrict oxygen uptake by gill tissue. Vogel (1959) and Sparks (1972) reported chemical agent causes most damage at their site of entrance and exit from the body hence is the most important factor for gill damage because gill are the prime site of entrance and excretion.

The alterations in present study may also be due to alteration in cellular calcium fluxes or due to cytotoxic action on epithelial cells. Findings of present research work will be helpful to assess the degradation of aquatic bodies in relation to these economically important crustaceans which are on the top of foreign exchange earner among fisheries products.

\section{Conclusion}

The heavy metal lead was toxic to freshwater prawn, $M$. dayanum at histopathological level specially in gills which are primary site of respiration as well as osmoregulation and directly comes in contact with surrounding medium and toxicants.
Histology of gills can serve as potential and foremost bio-marker in comparison to isolate physiological and biochemical parameters especially in reference to metal toxicity. $M$. dayanum can serve as better bio-indicator in assessment of health of fresh water aquatic bodies.

\section{ACKNOWLEDGEMENTS}

Authors are thankful to Head department of Zoology, University of Lucknow, Lucknow and Head Department of Zoology, B.S.N.V.P.G. College, Lucknow for providing necessary laboratory facilities to carry out present work.

\section{REFERENCES}

1. Abraham, K. M. and Radha Krishna, T. (2002). Study on the gill of field crab, Paratelphusa hydrodromous (Herbst.) exposed to nickel. J. Environ. Biol. 23 (2): 151-155.

2. Anderson, J. T. and E. Baatrup (1988). Ultrastructural localization of mercury accumulation in the gills hepatopancreas, midgut and antennal glands of the brown shrimp, Crangon crangon. Aquat. Toxicol. 13: 309-324.

3. Anderson, M. B., Preslan, J. E., Jolibois, L., Bollinger, J. E. and George, W. J. (1997). Bioaccumulation of lead nitrate in red swamp crayfish (Procambrus clarkii). J. Hazardous Materials 54: 15-29.

4. APHA (1998). Standard Methods for the examination of water and waste waters. $20^{\text {th }} \mathrm{Edn}$. APHA, AWWA and WPCF Washington.

5. Asih, A. Y. P., Irawan, B. and Soegianto, A. (2013): Effect of copper on survival, osmoregulation, and gill structures of freshwater prawn (Macrobrachium rosenbergii, de Man) at different development stages. Mar. and Fresh. Behav. and Physiol. 46(2):75-88.

6. Brown, G. D. and Creedy, J. (1970). Experimental biology manual. Heinemann Educational Books Ltd., London. Pp 266.

7. Burman, S. C. and Lal, M. (1994). Studied the potential and properties of bioaccumulation of heavy metals $(\mathrm{Zn}, \mathrm{Cu}, \mathrm{Cd}$ and $\mathrm{Pb})$ in soil and industrially polluted fields. J. Environ. Biol. 15: 107-115.

8. Chopra, A.K., Pathak, C. and Prasad, G. (2009). Scenario of heavy metal contamination in agricultural soil and its management. J. of Appl. Nat. Sci. 1(1): 99-108.

9. Costa, H. H. (1965). Oxygen consumption of Gammarus in relation to toxic substances. Ceylon. J. Sci. (Biol. Sci.). 5 (2): 87-96.

10.Devi, M. and Fingerman, M. (1995). Inhibition of acetylcholinesetrase activity in the central nervous system of the red swamp crayfish, Procambarus clarkia, by mercury, cadmium and lead. Bull.Environ. Contam. Toxicol. 55:746-750.

11.Drury, R. A. B. and Wallington, E. A. (1980). Carletons histological techniques $5^{\text {th }}$ Edition.

12.Dutta, H. M., Munshi, J. S. D.; Roy, P. K.; Singh, N. K.; Adhikari; S. and Killius; J. (1996). Ultrastructural chages in the respiratory lamellae of the catfish, Heteropneustes fossilis after sublethal exposure to malathion. Environ. Poll. 92: 329-341.

13.Fontine, C. T. and Lightener, D. V. (1974). Observation on the phagocytosis and elimination of carmine particles injected in to the abdominal musculature of the white shrimp Penaeus Setiferus J. Invert. Pathol. 
24: $141-148$

14.Frías-Espericueta, M. G.; Abad-Rosales, S. M. Vargas-Jiménez, A.; Sarabia- Espinoza, T.; RodríguezSalas, B. A., Osuna-López1, I. and Voltolin, D. (2016): Synergistic Effects of Sublethal Concentrations of Cadmium and Zinc on Mortality, Growth and on Gills and Hepatopancreas Histological Structure of Litopenaeus vannamei Postlarvae. Turk. J. of Fisher. and Aqu. Sci. 16: 491-497.

15.Ghate, H. V. (1984). Gill melanization and heavy metals in fresh water prawn (Caridena rajadhari). Ind. J. Fish. 31 (3): 389 - 393.

16.Ghate, H. V. and Mulherker, L. (1979). Histological changes in the gills of two fresh water prawn species exposed to copper sulphate. Indian J. Exp. Biol. 17: $838-840$.

17.Gill, T. S.. Pant, J. C. and Tewari, H. (1988). Bronchial pathogenesis in a fresh water fish, Puntius conchonius (Ham), chronically exposed to sublethal concentration of cadmium. Ecotoxicol. Environ. Saf. 15 (2): $153-161$.

18. Hutcheson, M. S. (1974). The effect of temperature and salinity on cadmium uptake by the blue crab, Callinectes sapidus. Chesapeake Sci. 15: 273-281.

19.Jadhav, S. M. (1993). Impact of pollutions on some physiological aspects of the fresh water bivalve, Corbicula seriatella. Ph.D. Thesis, Marathwada University, Aurangabad (M.S).

20.Jarup, L. (2003). Hazard of heavy metal contamination. Br. Med. Bull. 68: 167-182.

21.Khangarot, B. S. and Tripathi, D. M. (1990). Study of the gill damage to catfish, Saccobranchus fossilis following exposure to chromium. Water. Air. Soil. Pollution. 53: 379-390.

22.Kumari, S. A. and N. S. R. Kumar (1995). Effects of water pollution on the histology of fish Channa striatus in Hussainasagar, Hyderabad. India. Environ. Ecol. 13 (4): 932-934.

23.Kutlu, M. and Sumer, S. (1998). Effects of lead on the activity of S-aminolevulinic acid dehydratase in Gammarus pulex. Bull. Environ. Contam. Toxicol. 60: 816-821.

24.LoveGrove, S. M. and Eddy, F. B. (1982). Uptake and accumulation of zinc in juvenile rainbow trout, Salmo gairdenri. Environ. Biol. Chem. 193: 265-275.

25.Lucu, C. and Towle, D.W. (2003). Na+ + K+ ATPase in gills of aquatic crustacea. Comp. Biochem. Physiol. 135A:195-214.

26.Mason, C. F. (1996). Biology of freshwater pollution, $3^{\text {rd }}$ edn., Longman, U.K. pp1-4.

27.Mishra, A., Chopra, A. K. and Shukla, S. (2016). Physiological responses of heart of tailless freshwater flea, Simocephalus vetulus (CrustaceaCladocera) under copper sulphate stress. CIB Tech J. Zoo. 5(3): 52-59.

28.Mobarak, Y. M. S. and Sharaf, M. M. (2011). Lead acetate induced Histopathological changes in the gills and digestive system of silver sailfin molly (Poecilia latipinna). Int. J. Zool. Res. DOI: 10.3923/ ijzr.2011 (ISSN 1811-9778).
29.Nimmo, D. W. R., Lightner, D. V. and Bahner, L. H. (1977). Effects of cadmium on the shrimps, Penaeus duorarum, Palaemonetes pugio and Palaemonetes vulgaris. Physiological responses of marine biota to pollutants. Academic Press. Inc. New York.

30. Olojo, E. A. A. Olurin, K. B. Mbaka, G. and Oluwemimo, A. D. (2005). Histopathology of gill and liver tissues of the African catfish Clarias garipinus exposed to lead. African J. Biotech. 4(1): 117-122.

31.Parashar R. S. and Banerjee, T. K. (2002). Toxic impact of lethal concentration of lead nitrate on the gills of air breathing cat fish Heteropueustes fossili (Bloch) Veteran. Arch. 72 (3), 176-83.

32.Patwardhan, S. S. (1937): The Indian zoological memoires, on Indian animal types (VI) Palaemon (the Indian river prawn). Lucknow publishing house Lucknow. Pp 100.

33.Pequex, A. (1995). Osmotic regulation in crustaceans. J. Crust. Biol.15:1-60.

34.Putranto, T. W. C.; Andriani, R.; Munawwaroh, A.; Irawan B. and Soegianto, A. (2014). Effect of cadmium on survival, osmoregulation and gill structure of the Sunda prawn, Macrobrachium sintangense(de Man), at different salinities. Mar. and Fresh. Behav. and Physiol. 47(5):349-360.

35.Rouzbahani, M. M. (2017). Bioaccumulation of heavy metals $(\mathrm{Ni}, \mathrm{V}, \mathrm{Cu}, \mathrm{Pb})$ in various tissues of Metapenaeus affinis in the Northwest of Persian Gulf. Iranian J. of Aqu. Ani. Health, 3(1): 101-113.

36.Sabu, A. S., Sanil, N. K. and Nammalwar, P. (2017). Effect of cadmium in the gills of green tiger prawn, Penaeus semisulcatus. Int. J. of Fisheries and Aqu. Stud.; 5(1): 467-478.

37.Sen, P., Tiwari, K. J., Shukla, S., Shukla, R. and Sharma, U. D. (2008). Effects of cadmium on ventilation and oxygen consumption of freshwater prawn, Macrobrachium dayanum (Crustacea - Decapoda). Aquacult 9(1): 95-100.

38.Sharma, R. K. and Agrawal, M. (2005). Biological effects of heavy metals: An overview. J. Environ. Biol. 26 (2): 301-313

39.Sharma, U. D. and Shukla, S. (1990). Behaviour dysfunction of fresh water prawn, Macrobrachium lamarrei (Crustacea: Decapoda) following exposure to synthetic detergent, linearalkyl benzene sulphonate. Biol. Mem. 16(12): 58-61.

40.Shukla, S. and Sharma, U. D. (2010). Smaller freshwater Prawns: Their Aquaculture Potential and Suitability as good laboratory Model. In: Bioresources for food security and rural livelihood eds. G.K. Kulkarni and B. N. Pandey. Pp: 189-2014. Nalanda Publishing House, New Delhi.

41.Soegianto A, Charmantier-Daures M, Trilles J, Charmantier G (1999a). Impact of cadmium on the structure of gills and epipodites of the shrimp Penaeus japonicus (Crustacea: Decapoda). Aqua. Liv. Reso. 12:57-70.

42.Soegianto, A., Charmantier-Daures, M., Trilles, J.P. and Charmatier, G. (1999b). Impact of cadmium on the structure of gills and epipodites of the shrimp Penaeus japonicus (Crustacea: Decapoda). Aqua. Liv. Reso., 12: 57-70.

43._Soegianto, A.; Asih, A. Y. P. and Irawan, B. (2016). 
Lead toxicity at different life stages of the giant prawn (Macrobrachium rosenbergii, de Man). Considerations of osmoregulatory capacity and histological changes in adult gills. Mar. and Fresh. Behav. and Physiol. 49(3):187-200.

44.Sparks, A. K. (1972). Invertebrate pathology: Non communicable disease academic press New York/ London.

45.Tripathi, R., Shukla, S. and Sharma, U. D. (2019). Seasonal changes in reproductive cycle of female freshwater prawn Macrobrachium dayanum (Handerson) from river Gomti, Lucknow (India). J. App. Nat. Sci. 11(1) 149-154.

46.Verma, D. R., Lodhi, H. S., Tiwari, K. J., Shukla, S. and Sharma, U. D. (2010). Copper sulphate induced changes in scaphognathite oscillations and oxygen consumption of freshwater prawn, Macrobrachium lamerrei (Crustacea-Decapoda). J. App. Nat. Sci. 2 (1) $34-37$.

47.Victor, B., S. Mahalingam and R. Sarojini (1990). Gill Pathology and haemocyte response in mercury ex- posed Macrobrachium idea (Heller). J. Environ. Biol. 11(1): 61-65.

48.Vinod Kumar and A.K. Chopra (2015). Heavy metals accumulation in soil and agricultural crops grown in the Province of Asahi India Glass Ltd., Haridwar (Uttarakhand), India. Adv. in Crop Sci. Technol., 4: 203. doi:10.4172/2329-8863.

49.Vogel, F. S. (1959). The deposition of exogenous copper under experimental conditions with observations on its neurotoxic and nephrotoxic properties in relation to Wilson's disease. J. Exp. Med. 10: 801810.

50.Wu, J. P., Chen, H. C. and Huang, D. J. (2009). Histopathological Alterations in Gills of White Shrimp, Litopenaeus vannamei (Boone) After Acute Exposure to Cadmium and Zinc. Bull Environ Contam. Toxicol. 82:90-95

51.Yamuna, A., Saravana Bhavan, P. and Geraldine P. (2009). Ultrastructural observations in gills and hepatopancreas of prawn Macrobrachium malcolmsonii exposed to mercury. J. Environ. Biol. 30(5) 693-699. 